\title{
FORTIFICATION OF PLANT MAINTENANCE MANAGEMENT PRACTICES: ROLE OF SIX SIGMA APPROACH
}

\author{
Mahesh Pophaleya; Ram Krishna Vyas \\ ${ }^{a}$ Acropolis Technical Campus, Indore, India \\ ${ }^{\mathrm{b}}$ International Institute of Professional Studies (DAVV), Indore, India
}

\begin{abstract}
Today, only those companies which are capable of permanent and fast adaptation to quickly-changing conditions can survive. Six Sigma is at the top of the agenda for many manufacturing companies that try to reduce cost, process variability and improve productivity. In order for a company to remain competitive and maintain maximal efficiency and availability of all its plants and machinery, what is needed is an approach different from the traditional concept of doing plant maintenance. In this paper an attempt is made to investigate the gap between plant maintenance practices and Six Sigma approach that led us to suggest that there is a great deal of scope in the prescription of Six Sigma in maintenance theory. Further, this paper explores the possibilities of enhancing the usefulness and effectiveness of plant maintenance practices by the integration with established Six Sigma Operation Techniques (SSOT). Thus to enhance maintenance deployment in manufacturing environments, a new roadmap for core maintenance professionals for integration has been proposed. The conclusion that can be drawn from this ongoing research, in an automobile industry is that, in order to reach its goals, the maintenance departments must implement Six Sigma program to change the way in which traditional practices employ at work for continual improvement of the maintenance function.
\end{abstract}

Key-words: Maintenance, Six Sigma, DFSS, DMAIC, PACE

\section{INTRODUCTION}

It is obvious that there is a need now for a paradigm shift in maintenance strategy management to be put in place. The global business competition has turned out the nature of operations management to be a dynamic and complex system; maintenance function is no exception. It needs a new stratagem in order to achieve, even retain, a high maintenance performance level. The strategy that can shift people's mindset from just solving the maintenance problem per se to understanding better the equipment failure behaviour so as to recognise the true root cause of failure (Yuniarto et LawlorWright, 2009).

Extending the life of machinery through a productive maintenance strategy is one way organizations can innovate where as a lack of preventive maintenance will lead to expensive breakdown of capital equipment. However, many organisations perceive maintenance as a "necessary evil" and fail to recognise it as an integral cog for organisational sustainability (Seow and Liu, 2006). The major objective of any maintenance function is to see that machines and equipments are maintained in a way that enables a plant to manufacture its products with the lowest unit cost consistent with the safety and well being of the workers. It is often costly to over-maintain or under-maintain machines and equipments. Maintenance function is also expected to support popular manufacturing systems such as Just in Time, Lean Manufacturing etc. (Cooper, 2004; Pophaley et Vyas, 2010).

The Six Sigma approach is one of the more recent initiatives adopted by organisations that seek to make a paradigm shift in performance improvement (attacking at least one of the Cost, Quality, Delivery, Flexibility measurements for improved competitiveness). One could argue that it is not the recent initiative suggested, as Motorola conceptualized Six Sigma in the 1980s, but it has taken many years for it to be adopted on a global scale.

Whilst there is significant research information available on implementing effective maintenance and Six Sigma systems in a sequential manner, there is little information available relating to the integration of these approaches to provide a single and highly effective strategy for change in companies (Thomas et al., 2006). This paper proposes an 
Brazilian Journal of Operations \& Production Management

Volume 12, Número 1, 2015, pp. 56-64

DOI: 10.14488/BJOPM.2015.v12.n1.a6

integrated approach to Maintenance Excellence (ME) and Six Sigma which was developed as a result of research work underway in an automobile industry. The effectiveness of the approach is yet to be evaluated highlighting the benefits the host organization will experience through this new approach by measuring the effects of implementation against the Quality, Cost, Flexibility and Delivery (QCFD) measures.

\section{Organization of the Paper}

The rest of the paper is organised as follows: The literature on the use of the maintenance and Six Sigma for process improvement is considered in the next section. After detailed study a conceptual framework is presented in section 3 which pave the path for this research work. The various SSOT approaches are explained in section 4 and their linkage with ME is proposed in Section 5. The methodology and recommendations are presented in Section 6. Finally, the paper concludes with a summary, highlighting the important findings and a list of references.

\section{SIX SIGMA AND MANAGEMENT THEORY}

Six Sigma is a systematic, highly disciplined, customercentric and profit-driven organization-wide strategic business improvement initiative that is based on a rigorous process-focused and measurement driven methodology. Six Sigma makes use of sound statistical methods and quality management principles to improve processes and products via the Define-Measure-Analyze-Improve-Control, quality improvement framework to meet customer needs on a project-by-project basis. With many high-profile adoptions by companies such as General Electric in the 1990s, Six Sigma has spread like wild fire towards the end of the 20th century (Tang et al., 2007).

Six Sigma's origin and pattern of diffusion are quite different from those of other management and organizational innovations that have swept through the business world. Most contributions to modern management theory and technique have originated in the social sciences (Grant, et al., 1994). The theoretical basis of Six Sigma, however, is statistics. The pioneers of Six Sigma worked primarily within industry rather than in universities. Their backgrounds were mainly industrial engineering and management. However, the R\&D centers for most modern management ideas and techniques have been the leading business schools and management consulting companies. In this sense it shares similar traits with the evolution followed by other quality management approaches such as Total Quality Management (TQM). Nonetheless, unlike the TQM approach, the dissemination of Six Sigma has been hierarchical (Llore'nsMontes and Molina, 2006).

\section{Six Sigma-Success Story}

Approaches to business improvement have evolved and grown since the early 1900s and today the process focused, statistically driven Six Sigma methodology has been widely used by companies such as GE, Motorola, Honeywell, Bombardier, ABB, Sony, Kodak, DuPont, Dow Chemical, Whirlpool, American Express, IBM, Ford and many other and reported a substantial improvement in the business performance and bottom-line benefits (Kumar et al., 2006; Llore'ns-Montes et Molina, 2006). Some of the Indian companies implementing Six Sigma are Asian Paints, Citicorp, TATA Consultancy Services, Tata Honeywell, Birlasoft, Cummins India, ICICl Bank, Taj Hotels, L\&T Switchgear, ONGC, GE Capital, Patni Computers, TVS Suzuki, SKF Bearings, Reliance, Pidilite Industries, Wipro Infotech, Satyam Computer Services etc. (Market Scenario \& BSNL status).

Six Sigma is a highly statistical quality improvement technique, born in the manufacturing bays of Motorola in the mid-1980s, has been used at an operational level to help cut costs, improve processes, and reduce business cycle times. The basic concept of Six Sigma was initially developed by Mikel Harry in 1987, who worked at Motorola. The Six Sigma is based on the statistical techniques and quality improvement activities (Llore'ns-Montes et Molina, 2006). Motorola was instrumental in the initiation of Six Sigma. In fact the phrase "Six Sigma" was coined by Motorola. They further stated that a defect is anything that results in customer dissatisfaction. To achieve Six Sigma quality, a process must produce no more than 3.4 defects per million opportunities. An opportunity is defined as a chance for nonconformance, or not meeting the required specifications. Motorola reported 5-Fold growth in sales, profits climbing by $20 \%$ p.a. and a cumulative savings of $\$ 14$ billion over 11 years (Market Scenario \& BSNL status).

GE broadened Six Sigma's appeal world-wide by its adoption and endorsement from the legendary CEO Jack Welch, who quoted, 'Six Sigma 'GE Quality 2000,' will be the biggest, the most personally rewarding, and, in the end, the most profitable undertaking in our history". This was following GE Capital's 1998 performance when over $\$ 300,000$ million were generated in net income from Six Sigma quality improvements (Best Practices, LLC). Sony manufacturing company embarked on such a programme in 1997 through the commitment of Managing Director Mike Rigby, whose mission was to get better, faster. Rigby 
addressed his management team with a definition of insanity: 'Continuing to do the same things but expecting a different result!' The Six Sigma approach was chosen because it changes the way problems are addressed and is appropriate for the whole organisation.

\section{SIX SIGMA AND INDUSTRIAL MAINTENANCE}

The era 'from 1986 to 1990 ' has been referred to as the first generation of Six Sigma, or SSG 1 in the literature. It focused on the elimination of defects, improving product and service quality, reducing cost and continuous process improvement. In the 1990s, the focus of Six Sigma shifted from product quality to business quality referred to as the second generation of Six Sigma, or SSG 2 and Six Sigma became a business-centric system of management. Six Sigma - Third Generation (Gen 3) developed after the year 2000. In this generation many new developments took place like integration of Lean Manufacturing Techniques and Six Sigma, termed as Lean Six Sigma etc. During this time an integration of maintenance with Six Sigma has also been proposed.

To improve the maintenance process the concept which enables maximal efficiency of plants must take into account the entire system, man-plant-environment; besides, it must apply continual measures to prevent all losses. This is possible to achieve by applying Total Productive Maintenance (TPM) and Six Sigma concept in the maintenance of plants, which, through autonomous maintenance, places greater responsibility on operators concerning the state of the plant they are in charge of, which relieves maintainers, develops mutual confidence between operators and maintainers, increases the morals, and ensures greater commitment to work (Milosavljević et Rall, 2005; Kumar et al., 2006).

Seow et Liu (2006) focused in their study on the maintenance strategy, which was an effective approach of extending lifetime of equipments and improving product quality and system efficiency. A qualitative research study was undertaken in a food and beverage organisation in Malaysia to explore how customizing the deployment of the ethos behind Six Sigma, Small and Medium Enterprises (SME's) are able to bring the TPM strategy to be in greater alignment to that of the business strategy for the organisation it serves. They proposes Six Sigma + TPM=Corporate Sustainability. Table 1 highlights that Six Sigma and TPM are not mutually exclusive, but are mutually supportive in that they complement each other's shortcomings: Six Sigma's apparent lack of people orientation and TPM's over-indulgence to people oriented team-based continual improvement efforts.

Table 1. Six Sigma and TPM: Mutually supportive (Seow et Liu, 2006).

\begin{tabular}{|c|c|c|c|c|c|}
\hline SIX & Design & Measure & Analyse & Improve & Control \\
\hline TPM & $\begin{array}{c}\text { Identify } \\
\text { equipment } \\
\text { performance }\end{array}$ & $\begin{array}{c}\text { Measure } \\
\text { it }\end{array}$ & $\begin{array}{c}\text { Analyse } \\
\text { the } \\
\text { losses }\end{array}$ & $\begin{array}{c}\text { Improve } \\
\text { it }\end{array}$ & $\begin{array}{c}\text { Develop } \\
\text { maintenance } \\
\text { schedule to } \\
\text { control it }\end{array}$ \\
\hline
\end{tabular}

\section{THE CONCEPTUAL FRAMEWORK}

Six Sigma and Maintenance Excellence as performance improvement initiatives cannot remain stagnant if they have to sustain their value for businesses beyond the initial waves of applications. To develop a conceptual framework Operations Research and Management Science (OR/MS) technique is used. As implied by the name, they are concerned with the conduct and improvement of 'operations' as well as the 'practical management' of organizations.

OR/MS techniques have been extensively applied to a wide range of areas including transportation, manufacturing, telecommunication, the military, financial planning, public services and healthcare. They are effective tools for improving the efficiency and productivity of organizations. Another important characteristic of OR/MS is that, rather than simply improving the status quo, its primary goal is to identify a best possible course of action. This is also a fundamental goal of all Six Sigma projects, commonly exemplified through the 'Improve' phase. Consequently, it is quite natural to integrate techniques into the framework of Six Sigma (Tang et al., 2007).

As an outcome of this research work an M-framework is proposed for improving the effectiveness of Plant Maintenance. Thus the function of Six Sigma is to simultaneously improve quality (both internally and delivered-to-customer) and delivery, which will raise customer satisfaction and drastically reduce costs of rework, repair and re-inspect. This is illustrated by the ' $M$ ' structure in Fig. 1. This $M$ stands for maintenance when integrated with Six Sigma as conceptual framework for this paper.

Historical management practices have been to increase output at the expense of quality or vice versa. Six Sigma 
Brazilian Journal of Operations \& Production Management

Volume 12, Número 1, 2015, pp. 56-64

DOI: 10.14488/BJOPM.2015.v12.n1.a6

enables increased output and improved quality by reducing variation and optimizing processes. Process knowledge is the key to the approach, as the Six Sigma axiom is 'to gain process knowledge to understand how key process input variables affect key process output variables-and act on it'. The essential elements of any Maintenance Evaluation Programme (MEP) are summarized in table 2 as key processes in any industrial maintenance function.

Evaluation of maintenance performance is admittedly a difficult task. It is not possible to select a single criterion, which gives a meaningful measure of performance in the wide array of plants and processes that we come across. It is also impossible to select any single measure with which to gauge maintenance performance. Fair evaluation demands the use of many factors. A comprehensive list of conventional and contemporary, concepts and methods of evaluation of maintenance performance have been available in literature. Before adopting any, a specific organization should judiciously choose one or combination of approaches and more importantly analyse, interpret and use the information, generated and gathered (Thomas et al. 2008; Pophaley et Vyas, 2010).

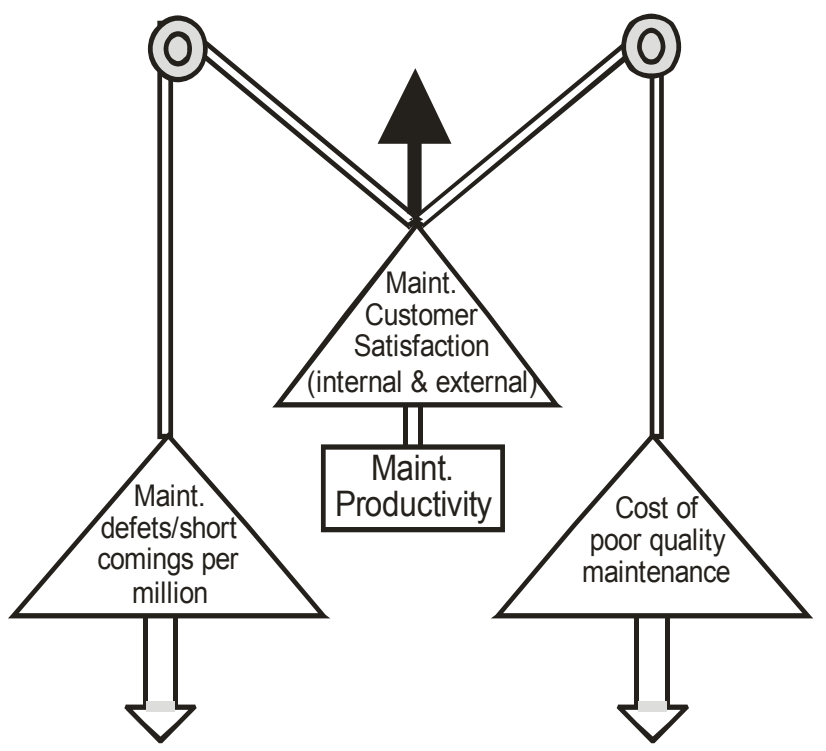

Figure 1. Conceptual Framework.

\section{THE PROPOSED METHODS FOR IMPROVING MAINTENANCE PROCESS}

There are various methods gaining momentum in industry; however, academics have conducted little research on this emerging phenomenon as applied to industrial maintenance and thus not very well covered and reported as such. We recommend three methods for improving maintenance process namely DFSS, DMAIC and PACE.
Table 2. Essential Elements of MEP.

\begin{tabular}{|l|}
\hline Maintenance organization structure \\
\hline Maintenance policy and procedures \\
\hline Maintenance planning and scheduling \\
\hline Maintenance cost \\
\hline Maintenance strategy \\
\hline Maintenance work measurement \\
\hline Maintenance work load control \\
\hline Maintenance spares inventory control \\
\hline Maintenance budget \\
\hline Maintenance personnel training \\
\hline Maint. work reporting and record keeping \\
\hline Computerized maintenance management \\
\hline $\begin{array}{l}\text { Safety and environmental issues in } \\
\text { maintenance }\end{array}$ \\
\hline
\end{tabular}

The DFSS (which is an acronym for Design for Six Sigma) focuses on generating new processes, services and/or equipments to meet customer needs (Critical to Quality) at the Six Sigma level. Design for Six Sigma can be seen as a subset of Six Sigma focusing on preventing maintenance problems, instead of just fixing those (Lazreg et Gien, 2009). While it shares many of the principles of Six Sigma, DFSS goes further upstream to recognize that decisions made during the design phase of equipments profoundly affect the quality and cost of maintenance activities to deliver the quality product (Huber et Mazur, n.d.). Design for Six Sigma is a methodology for designing new equipment or for redesigning existing one. Thus applying DFSS maintenance processes can be analysed and evaluated for improvement as illustrated in figure 2 .

The DMAIC (which is an acronym for Define, Measure, Analyze, Improve and Control) focuses on improving existing processes and performance (Thomas et al., 2006). Traditionally under Six Sigma approach, a five-phased DMAIC methodology is applied that tackles specific problems to reach Six Sigma levels of performance (Breyfogle, 1999). These phases are (Thomas et Lewis, 2007):

Phase 1 - (D)efine - Who are the customers (internal/ external) and what are their priorities?

Phase 2 - (M)easure - How is the maintenance function measured and how is it performing?

Phase 3 - (A)nalyse - What are the most important causes of defects/rework?

Phase 4 - (I)mprove - How do we remove the causes of the defects?

Phase 5 - (C)ontrol - How can we maintain the improvements? 
The DMAIC methodology should be used when a maintenance process is in existence at an industry but is not meeting customer specification or is not performing adequately to achieve the targets. There are various tools available to perform these analysis e.g. flow charts, check sheets, Pareto diagram, cause/effect diagram, scatter diagram, tree diagram, affinity diagram, Quality Function Deployment (QFD), Design of Experiment (DOE), risk analysis, simulation etc. Figure 3 shows the general framework for this technique, in which the input and output are varying as the maintenance process taken under consideration varies.

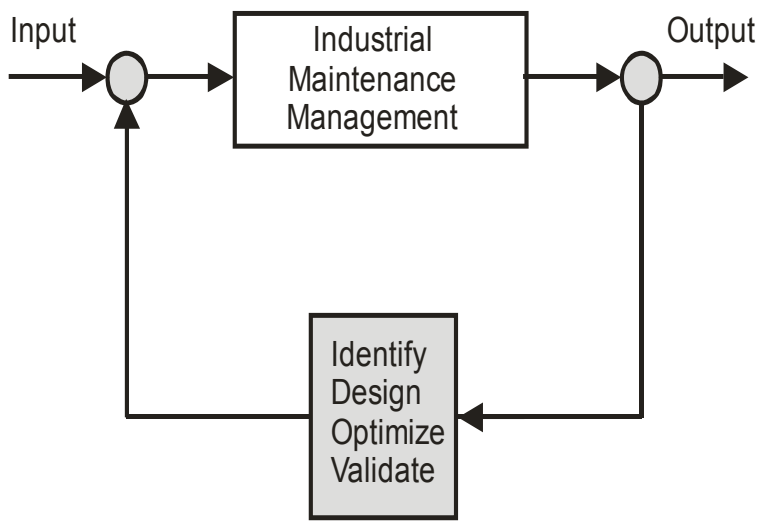

Figure 2. DFSS and Maintenance Function.

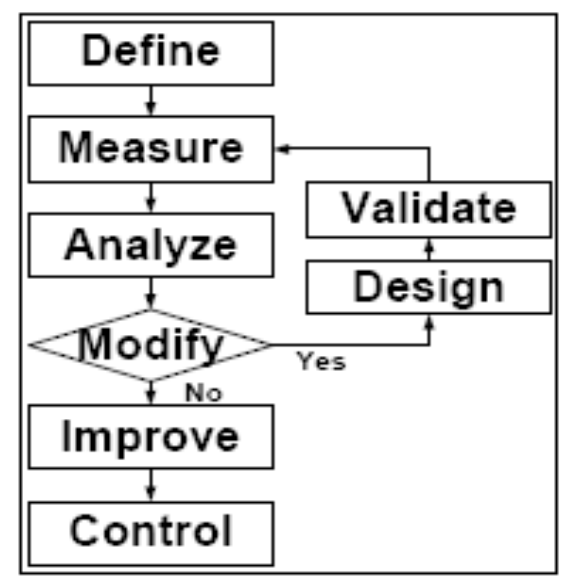

Figure 3. DMAIC in Maintenance (Huber et Mazur, n.d.).

PACE Framework: We can apply a methodology to benchmark maintenance practices that evaluates the maintenance department's pressures, actions, capabilities, and enablers (PACE) that indicate its behavior in specific processes. These terms are elaborated from maintenance management point of view in table 3, keeping the same basis as reported in 'The Lean Six Sigma Benchmark Report'.
Table 3. The PACE framework.

\begin{tabular}{|l|l|}
\hline Pressures & $\begin{array}{l}\text { External forces that impact a } \\
\text { maintenance organization's position, } \\
\text { competitiveness, or practices (e.g., } \\
\text { economic, regulatory, technology, } \\
\text { changing customer preferences and } \\
\text { competitiveness). }\end{array}$ \\
\hline Actions & $\begin{array}{l}\text { The strategic approaches that a } \\
\text { maintenance organization takes } \\
\text { in response to industry pressures }\end{array}$ \\
$\begin{array}{l}\text { (e.g., align the maintenance model } \\
\text { to leverage industry opportunities, } \\
\text { such as production strategy, financial } \\
\text { strategy, and material strategy). }\end{array}$ \\
\hline Capabilities & $\begin{array}{l}\text { The maintenance process } \\
\text { competencies required to execute } \\
\text { maintenance strategy (e.g., skilled } \\
\text { people, feasible tools/equipments/ } \\
\text { services available, financing). }\end{array}$ \\
\hline Enablers & $\begin{array}{l}\text { The key functionality of technology } \\
\text { solutions required to support the } \\
\text { maintenance organization's practices } \\
\text { (e.g., information development } \\
\text { platform, applications, information } \\
\text { connectivity, user interface, training } \\
\text { and support, data cleansing and } \\
\text { management). }\end{array}$ \\
\hline
\end{tabular}

\section{INTEGRATING MAINTENANCE EXCELLENCE AND SIX SIGMA}

Several methods are proposed in the literature for improvement in maintenance (Lazreg et Gien, 2009). According to literature, several companies continue to improve their maintenance organisation through implementing various technological and managerial improvement approaches such as 5S, kaizen, Computerised Maintenance Management System (CMMS), Vibration Monitoring etc. which are collectively called as Maintenance Excellence. Excellence is better than the best, which means that there is always something which can be better than the existing, i.e. that it is possible to achieve the vision of zero errors, zero interruptions, zero dissipation of resources and substantially increased availability of plants and equipment etc. (Maintenance Genesis). To achieve something better than the existing means to explore the possibilities of improving the existing models and concepts of maintenance, and to, on this basis, propose an improved model of the maintenance process, which not only will meet all requirements of the ME philosophy, but also the requirements of Six Sigma concept.

Thus integrating SSOT and ME could be the most popular approach in recent years, but there is few written on linking 
them together. This article aims to highlight the synergy of these approaches and seeks to integrate them into one form. Linking Six Sigma and ME leads to an improved model of the organisation of the maintenance function, enables reduction of variations in the process and cycle time for the maintenance, eliminates the waste and rework etc. In this view, the integrated model supports progressive improvement and helps the organisation define its improvement priorities and reach new levels of competitive strength (Lazreg et Gien, 2009).

Despite their role in improving performance, these frameworks have important drawbacks as improvement models, especially, given the lack of their implementation in manufacturing, their integration into the everyday organisational operations. As per Lazreg et Gien, (2009), the following deficiencies could be noticed:

- They are often too complex to be applied as such by small organizations;

- Maintenance Excellence has been treated as a separate activity then SSOT;
- The implementation process of these models is still under-researched area.

With proper interaction between these two approaches and company-wide involvement with full capability, these shortcomings can be removed and new horizons of improvement and innovation can be reached. The goal is to have disciplined control of the maintenance process such as the potential breakdown/rework and defects are avoided, when they do occur; the cause is immediately addressed and eradicated. The approach is not only to correct the existing maintenance process, but also to extend it and redesign the maintenance organisation if required. In the process of progressive improvement, as shown in Figure 4 and 5 , the focus is on the identification of the maintenance requirements, technical improvement, elementary tasks, implementation of targeted solutions and monitoring plan. Figure 5 is an integrated model conceived from the idea presented by Milosavljević et Rall (2005).

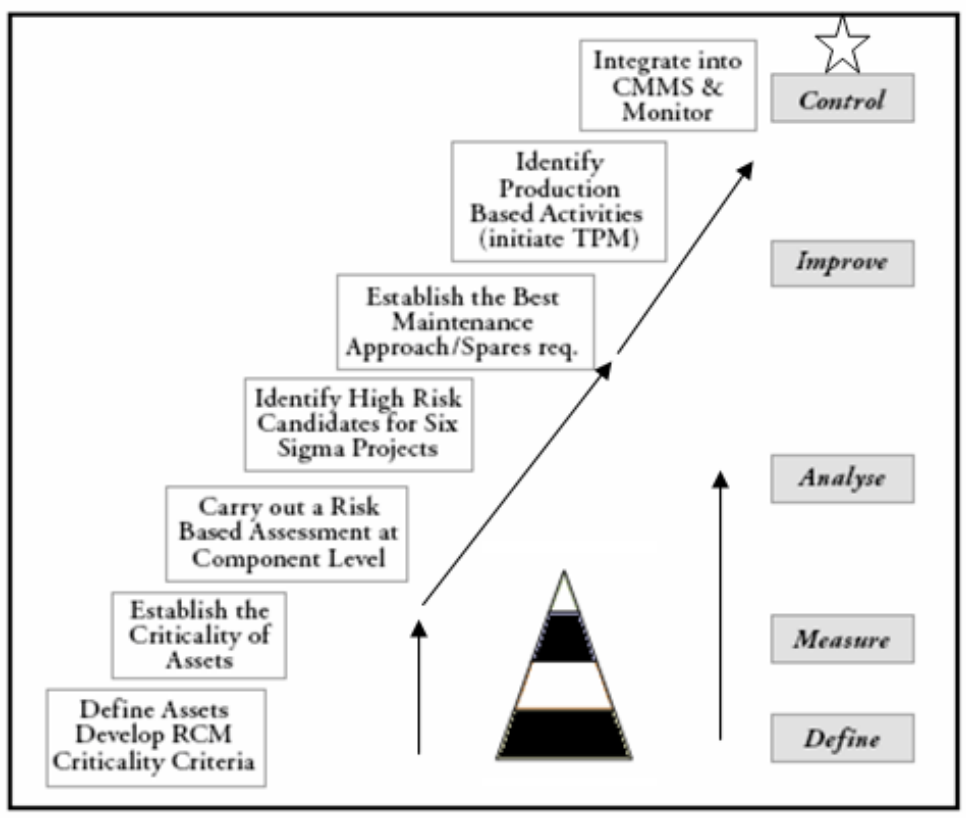

Figure 4. Maintenance Excellence and Six Sigma approach (Davies, 2009). 


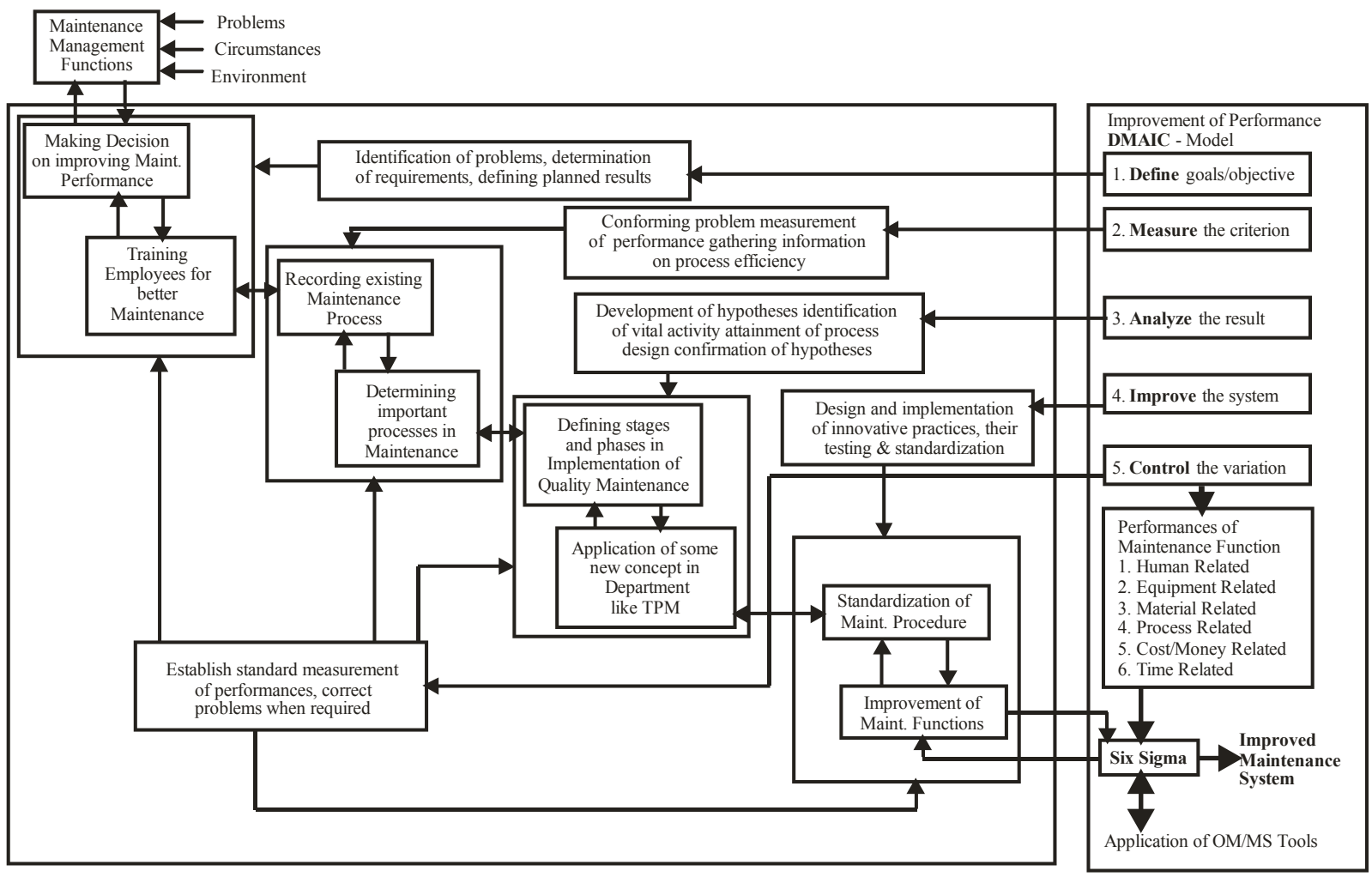

Figure 5. Integrated model of SSOT \& ME for progressive improvement in maintenance.

\section{RECOMMENDATIONS FOR ACTION}

Figure 6 shows a proposed pilot plan implementation road map for presented methods. Based on the recommendations given in 'The Lean Six Sigma Benchmark Report', implementing companies should evaluate their maintenance practices effectively to ensure that they

- Apply metrics of DPMO (Defects per Million Opportunities) across all maintenance processes, not just manufactured products and parts;

- Identify and prioritize maintenance impact projects according to anticipated savings and improved throughput. Look first for low hanging fruit and act now for immediate benefit;

- Identify maintenance process and project owners who will accept ownership of and accountability for the continuous improvement process;

- Must follow new methods suggested (the process owners), that lead to continuous improvement. This discovery process is an important aspect of developing equipment ownership for improvement and driving real results in maintenance organizations;

- Integrate data collection with analysis.

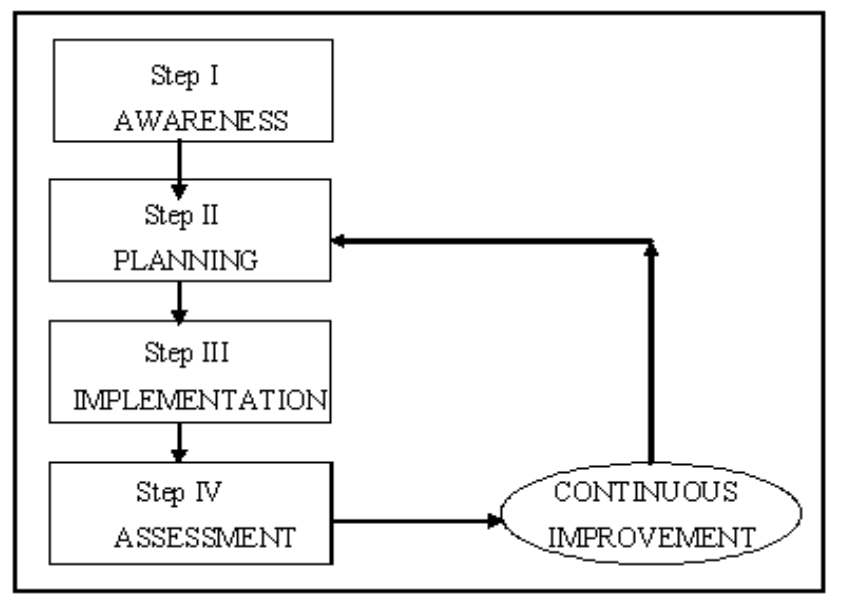

Figure 6. Pilot plan implementation Road Map.

\section{CONCLUSION}

The Six Sigma is a concept that has gained interest among executives in various industries and maintenance executives are not the exceptions. Further as a result of hurried industrialization, major production activities are rapidly being transferred from human hands to machines and automated equipments. To increase the rate of production 
Brazilian Journal of Operations \& Production Management

Volume 12, Número 1, 2015, pp. 56-64

DOI: 10.14488/BJOPM.2015.v12.n1.a6

the relative speeds of the machines and equipments are also increasing causing high rate of wear and tear, deterioration and failures. Thus maintenance departments are continually under the gun to restore the machines to their original operating conditions, decrease equipment downtime, minimize wear and tear, improve efficiency and reduce costs on a long term basis. Only an effective maintenance system can ensure it. The goal of this article is to explore the relationship between the principles of Six Sigma and those of maintenance theory from a perspective based on improving maintenance organization effectiveness. Moreover, we explore the behavioral processes that are central to maintenance and Six Sigma and proposed an integrated model of ME and SSOT to improve maintenance process. As previously suggested a typical Six Sigma programme will not directly address the maintenance of plant and machinery but it will provide personnel with the necessary skills, knowledge and attitude to implement the elements of a world class maintenance programme. The equipment management policy, maintenance strategy and objectives for the organization should be developed with due consideration for the Six Sigma programme mission and objectives and also the mechanisms that SSOT provides for the resolution of major reliability and maintainability problems.

All truth passes through three stages. First, it is ridiculed. Second, it is violently opposed. Third, it is accepted as being self-evident.

Schopenhauer

\section{REFERENCES}

Best Practices, LLC. Available: http://www.best - in- class. com/research/bestpratice/six_sigma_25.htm.

Breyfogle, F.W. (1999) Implementing Lean Six Sigma, Smarter Solutions-Using Statistical Methods. Chichester; John Wiley \& Sons Inc.

Cooper, H.C. (2004) Six Sigma Keys to Lean Maintenance. Maintenance Technology, November, pp.23-25.

E2-E3 Telecom Factory Core 'Six Sigma', Market Scenario \& BSNL status, Available at http://61.1.239.25/E2-E3/ E2-E3\%20TF/E2E3\%20TF\%20PDF\%20for\%20PPT/Ch\%20 8\%20\%20E2E3\%20TF\%20Six\%20Sigma.pdf.

Grant, R. M.; Shani, R. and Krishnann, R. (1994) TQM's Challenge to Management Theory and Practice. Sloan Management Review, winter, Vol. 35, No. 2, pp. 25-35.

Huber, C. and Mazur, G. H. (n.d.) QFD and Design for Six Sigma, $14^{\text {th }}$ Symposium on QFD, pp. 01-12, Available at http://www.mazur.net/works/qfd_dfss.pdf.
Kumar, M.; Antony, J.; Singh, R. K.; Tiwari, M. K. and Perry, D. (2006) Implementing the Lean Sigma framework in an Indian SME: a case study. Production Planning \& Control, Vol.17, No.4, pp.407-423. http://dx.doi. org/10.1080/09537280500483350

Lazreg, M. and Gien, D. (2009) Integrating Six Sigma and maintenance excellence with QFD. International Journal of Productivity and Quality Management, Vol.4, Nos.5/6, pp.676-690. http://dx.doi.org/10.1504/IJPQM.2009.025191

Llore'ns-Montes, F.J. and Molina, L. M. (2006) Six Sigma and Management Theory: Processes, Content and Effectiveness. Total Quality Management, Vol.17, No.4, pp.485-506. http://dx.doi.org/10.1080/14783360500528270

Maintenance Genesis, Available at http://www.scribd. com/doc/40776286/Maintenance-Genesis.

Milosavljević, P. and Rall K. (2005) Six sigma concept in the maintenance process of Technical systems. Facta Universitatis, Series: Mechanical Engineering, Vol.3, No.1, pp.93- 108.

Pophaley, M. and Vyas, R. K. (2010) A review on changing plant maintenance management performance measures in automotive industries, in $2^{\text {nd }}$ IIFTR international conference on Opportunities and Challenges in Global business.

Seow, C. and Liu, J. (2006) Innovation in Maintenance Strategy through Six Sigma: Insights of a Malaysian SME, in: International Conference on Management of Innovation and Technology, IEEE, pp.793-797.

Tang, L.C.; Goh, T.N.; Lam, S.W. and Zhang, C.W. (2007) Fortification of Six Sigma: Expanding the DMAIC Toolset. Quality and Reliability Engineering International, Vol.23, pp.3-18. http://dx.doi.org/10.1002/qre.822

The Lean Six Sigma Benchmark Report, September 2006, Aberdeen Group, Inc., Boston, Massachusetts, USA, www. aberdeen.com, pp. 1-22.

Thomas, A. and Lewis, G. (2007) Developing an SME-based integrated TPM-Six Sigma strategy. International Journal of Six Sigma and Competitive Advantage, Vol.3, No.3, pp.228247. http://dx.doi.org/10.1504/IJSSCA.2007.015067

Thomas, A.; Barton, R. and Byard, P. (2008) Developing a Six Sigma maintenance model. Journal of Quality in Maintenance Engineering, Vol.14, No.3, pp.262-271. http:// dx.doi.org/10.1108/13552510810899463

Thomas, A.J.; Jones, G.R. and Vidales, P. (2006) An Integrated Approach to TPM and Six Sigma Development in the Castings Industry, in: 2nd International Conference on Intelligent Production Machines and Systems, I*PROMS, Cardiff University. 
Yuniarto, H. A. and Lawlor-Wright, T. (2009) Root Cause Systemic Analysis: Improving maintenance performance with System Dynamics and Six Sigma, in: 7th Annual Conference on Systems Engineering Research, Loughborough University.

\section{BIBLIOGRAPHY}

Al-Mishari S. T. and Suliman, S. (2008), Integrating SixSigma with other reliability improvement methods in equipment reliability and maintenance applications. Journal of Quality in Maintenance Engineering Vol.14, No.1, pp. 5970.

Davies, R. (2009), Six Sigma \& World Class Maintenance. Plant Maintenance, Sep. - Oct., pp. 23-24.

Montgomery, D. C. (2008), Does Six Sigma Stifle Innovation? Quality and Reliability Engineering International, Vol.24, pp. 249.

Zu, X., Fredendall, L. D. et Douglas, T. J. (2008), The evolving theory of quality management: The role of Six Sigma. Journal of Operations Management, Vol.26, pp.630 $-650$. 